日本臨床麻酔学会第 39 回大会シンポジウム

日臨麻会誌 Vol.41 No.3, 256, 2021

\title{
「周術期死亡リスクの高い手術： 何を基準に麻酔を引き受けますか?」によせて
}

本シンポジウムでは，周術期死亡リスクの高い手 術を予定された患者に重篤な合併症がある場合に， 麻酔管理を引き受ける基準やどのように周術期管理 を行うべきなのかについて，それぞれ異なるテーマ で4人の先生からご講演をしていただき, 議論を行 った。その中からわれわれ麻酔科医が日ごろから頭 を悩ます,「心血管系リスク症例の周術期管理」と「糖 尿病患者の術前評価」について, 大西佳彦先生 (国 立循環器病研究センター), 門井雄司先生 (群馬大学 医学部附属病院)からそれぞれご講演内容をもとに ご執筆いただいた。

大西佳彦先生からは，術前の心血管系リスク重症 度評価における, 拡張能障害ならびに右心不全の程 度や日常の活動性に対する評価の重要性を冒頭にて お話していただいた。引き続き，手術の重症度と緊 急性を考慮したうえで心血管系リスクを減らすため の処置や手術を本来目的とする手術前に行うべきか どうか, 手術中の循環動態モニタリングはどのよう に行うべきか, そして大動脈バルーン・パンピング や経皮的心肺補助, 左室補助を行う Impellaなどの
補助循環の適応や実際の管理につき，ご自身の経験 された実際の症例を紹介しながらわかりやすく解説 していただいた。

門井雄司先生からは，日本では既に 2,000 万人以 上いる可能性のある糖尿病患者に対する周術期管理 についてのご講演をいただいた。糖尿病患者の術前 評価では, 血糖管理評価における $\mathrm{HbAlc} の$ 重要性, 血管病変の存在とそれによる虚血性心疾患が潜在し ている可能性，そして糖尿病性網膜症と脳血管障害 の存在との関係などについてのお話を頂戴した。ま た，麻酔管理上問題となる，挿管困難の可能性，自 律神経系異常に伴う注意点, 脳血流自動調節能の異 常，さらに実際の術前血糖コントロールはどの值を 目標にどのように行うべきか, についてご講演いた だいた。

心血管系リスクや糖尿病を合併した手術患者は 益々増加している。これらの患者の周術期管理をど のように行うべきなのか, お 2 人のご講演からはそ のはっきりとした答えが見えてくるであろう。 